\title{
REPORTS ON ICE CAVES IN LITERATURE FROM THE TWELFTH TO THE MIDDLE OF THE TWENTIETH CENTURY
}

\author{
Christiane Meyer ${ }^{1, \mathrm{C}}$, Andreas Pflitsch ${ }^{1}$, Julia Ringeis ${ }^{1}$, and Valter Maggi ${ }^{2}$
}

\begin{abstract}
The main goal of this paper is to summarize the history and the progress of ice cave research in the northern hemisphere as an introduction to the following papers about modern research in the U.S. We focus on the earliest descriptions of ice caves starting from the twelfth century, a cave with ice in India, as well as the beginning of modern ice cave research in the nineteenth and twentieth centuries. Moreover, we give a short overview of the different theories about ice caves over the course of time. The article is an introduction to the much younger ice cave research in the U.S., which will be the topic of a second paper in this journal.
\end{abstract}

\section{Ice Cave Research Over the Course of Time}

Ice cave research plays only a minor role in the research of ice and snow. Less visible and much smaller than the vast ice masses above ground, the more concealed subsurface ice has been of little interest to many researchers. However, beneath the surface are numerous ice formations with a great variety of forms ranging from ice monoliths several meters thick, to ice lakes, to delicate ice crystals millimeters in size. These icy features store a vast record of climate history.

Over the centuries, clergymen, amateurs, natural scientists, and locals have visited the subsurface world of ice to see this phenomenon themselves and to find an explanation for its existence. Over time, many theories about the development of ice caves have evolved, but as of today, the fundamental research has not been completed. Later in this paper, we will give a basic overview of the best-known ice cave theories.

As research often focuses on cost-benefit considerations, basic research without a clearly defined impact increasingly loses prominence. This questions the benefit of ice cave research in general. But just as the exploration of the most distant regions of the universe or the abyssal depths of the sea, ice cave research has the potential to create new knowledge. For example, one can learn about the regional and local climate history outside the mountainous regions that are covered by glaciers on the surface.

In a series of three papers in this journal, the historical, as well as the current research on ice caves, will be presented to review lost or forgotten knowledge and to attempt to revive and support ice cave research, which is stagnant in some countries. After an overview of the first records of underground ice in Europe and Asia, the second article covers the records and research in the United States. The third article is about our own research in gulch, talus, and slope ice in New England.

It is well known from the analysis of ice cores and pollen that the ice in some caves is several thousand years old, has outlasted several climatic temperature maxima, and is not a remnant of the Little Ice Age as was supposed in former times (Silvestru, 1999). Historic documents, for example, describe the complete extinction of ice from the Chauxlès-Passavant (France), which was followed by a new ice accumulation (Fugger, 1893).

When were ice caves first studied scientifically? What can we learn about the geographic distribution of ice caves from historical sources? Here we must take into account that research developed differently in different parts of the world, and we may learn more about the development of research than about the occurrence of ice caves. In general, we can state that the increase in knowledge was slowed due to the difficult accessibility of ice caves in mostly high mountain regions and the inconsistency of reports about the investigations. In addition, ice caves in more remote mountain ranges remained undiscovered for a long time. Therefore many ice caves have probably never been written about, or accounts of them are not accessible to us because of language barriers.

For the first part of this series, documents covering the occurrence of ice caves were evaluated. Works in German, English, French, and other European languages dating from the twelfth century until today were reviewed. Due to their age, it was not possible to view all of the known original sources. In cases where original documents were not accessible, multiple citations in secondary sources were used. Access to original sources is also complicated by the many different languages in which they are written. To date, there is no complete evaluation of the publications on ice caves. The surveys of Turri et al. (2009) or Mavlyudov (2008) are important studies and will be further complemented by this article.

\footnotetext{
${ }^{1}$ Department of Geography, Ruhr-University Bochum, Universitaetsstr. 150, 44801 Bochum, GERMANY

${ }^{2}$ Dipartimento di Scienze Ambiente e Territorio, University of Milano-Bicocca, Piazza della Scienza 1, 20126 Milan, ITALY

c Corresponding Author: christianemeyer@gmx.ch
} 


\section{First Historical Sources}

The first mention of an ice cave is found in a document from the twelfth century. In his chronicle of the kings of Kashmir, Kalhana describes the Armanath Cave (Stein, 1961). This cave, located in today's India, is still visited by pilgrims who worship an ice formation in the cave as the manifestation of a deity: "[...] the famous cave of Amarnath [...] In it S'iva Amarésvara is believed to have manifested himself [...] The god is worshipped in a lingashaped ice-block" (Stein, 1961, p. 41).

In the late fifteenth century, a report on an ice cave in the Carpathian region appeared, according to Schönviszky (1968). Petrus Ranzanus writes on an ice cave in the Hungarian kingdom: "[...] near Scepusium there are cliffs, where [...] water [...] in summer is frozen" (Ranzanus, 1977, p. 71, own translation, see original text I). From this time period we also have an account by Leonardo Da Vinci of Moncodeno ice cave in the Italian Alps: "These excursions are to be made in the month of May. And the largest bare rocks that are to be found in this part of the country are the mountains of Mandello near to those of Lecco, and of Gravidona towards Bellinzona, 30 miles from Lecco, and those of the valley of Chiavenna; but the greatest of all is that of Mandello, which has at its base an opening towards the lake, which goes down 200 steps, and there at all times is ice and wind"i (Richter, 1883, p. $238 \mathrm{f}$ [see text II], Balch 1900, p.211).

The best-known descriptions of a European ice cave date from the sixteenth century, when Poissenot (Poissenot, 1586, p. 436-453) and Gollut (Gollut, 1592, p. 88) write about the Chaux-les-Passavant and also give explanations of this phenomenon. Poissenot writes in a letter: "[...] having come to the cave, which we found of the length and width of a large hall, all surfaced with ice in the lower part [...] After having searched in my mind the cause for this antiperistase, I did not find another but this: namely it is that as the heat dominates in summer, the cold retreats to places low and subterranean like this to which the rays of the sun cannot reach" (Poissenot, 1586, p.265 [see text III], own translation).

Gollut notes: "[...] since at the bottom of a mountain of Leugne ice is found in summer, for the pleasure of those who wish to drink cool. Nevertheless at this time, this is disappearing, for no other reason (as I think) except, that they have despoiled the top of the mountain, of a thick and high mass of woods, which did not permit that the rays of the sun came to warm the earth, and dry up the distillations, which slipped down to the lowest and coldest part of the mountain where (by antiperistase) the cold got thicker, and contracted itself against the heats surrounding and in the neighborhood during the whole summer, all the external circumference of the mountain" (Gollut, 1592, p. 88 [see text IV] [translated by Balch, 1900, p. 202]). That Chaux-les-Passavant (also known as Baume or Grâce de Dieu) in the Jura Mountains is the cave discussed by those authors is confirmed by Schwalbe $(1886, p .7)$. Over the following centuries, there were several other publications on Chaux-les-Passavant. In 1885, Giradot and Trouillet published a monograph on it.

In the seventeenth century, there are the important descriptions by Valvasor of ice caves of the former archduchy Carniola dating from 1689, which became known as the earliest descriptions of ice caves in this region. By then, only individual sites were known and an ice cave was assumed to be a unique phenomenon. In the eighteenth and nineteenth centuries, this opinion changed, and descriptions of ice caves became more numerous.

\section{Before the Twentieth Century}

In the latest comprehensive literature research, Turri et al. (2009) evaluate sources, including Italian and Russian literature, and compile descriptions of ice caves in Europe and Asia and their geographical distribution. Mavlyudov (2008) and Turri et al. (2009) agree that the first mention of ice caves in Russia were from the Volga River valley in the year 1690, and both also list several publications on Russian caves from the eighteenth century, including the Kungur Ice Cave, from 1730. They also show that starting with the records of the ice caves in the French and Swiss Jura Mountains and in Slovenia, more and more descriptions of ice caves in Europe and east of the Ural were published. Another recent study with a focus on the Alps and Slovenia was published by Kranjc (2004).

In the nineteenth century, a number of review articles were published. The works of Schwalbe (1887), Fugger (1891 and 1893), and Balch (1900) contain extensive evaluations of original sources and compilations of ice cave locations known at that time. These publications also contain theoretical discussions concerning definitions of terms and theories of ice cave formation and processes. In 1865, Browne published a monograph in which he reports on several ice caves he had visited. He also included a literature review and an overview of ice cave theories. These publications extend the known source material considerably. For Eastern Europe, Fugger (1893) names the previously mentioned publication by Valvasor as the first document about this region. The documentation by Schwalbe (1887) is characterized by its geographical diversity. Schwalbe (1886, p. 13) emphasizes the importance of this aspect for the understanding of the existence of ice caves: "The geographic distribution is very important for the explanation of the phenomenon". At the same time he judges, "After all the phenomenon is rare and not widely spread" (see original text V).

In his final remarks Schwalbe $(1887$, p. 38 ) writes that most of the works he evaluated mainly consisted of simple descriptions of ice cave locations. Some reports included observations or measurements of the physical properties, but only a few described systematic research. Nevertheless, he thought that every record added some information helpful for the understanding of the phenomenon. 
The compilation of Balch (1900) includes about 300 locations worldwide in sedimentary and magmatic rock, including sites in different parts of Europe, Asia, and America.

The evaluation of source material shows that before the nineteenth century the knowledge on ice caves was still limited in the number of known locations. In addition to this, it was also geographically limited. Beyond Central Europe, and later Russia, locations of ice caves in other parts of the world became known much later.

In the nineteenth century, a large number of primary descriptions and other ice cave publications appeared, along with some of the first broad theoretical analyses about their formation. There was also great interest in understanding the distribution of ice caves. Figure 1 shows geographic regions in which ice caves were known to exist prior to the twentieth century. The compilation derived from the cited sources includes different types of natural caves, such as caves in soluble rock, caves in magmatic rock, and ice in artificial underground spaces such as mines. For many of the locations, it is not known whether they still have ice today.

\section{The Twentieth Century}

In the twentieth century, the assessment of ice caves changed. "Ice caves are [...] a very common phenomenon. Apart from the European limestone high mountain regions [...] they are found in the Jura Mountains, the Alpine foothills [...] Several hundred ice caves are known in the United States and in Canada [...] a very large number of ice caves can also be expected to exist on other continents of the northern and southern hemisphere. Provided that karstic rock is present, their occurrence above the 35th degree of latitude north or south seems to be ensured, with their height above sea level decreasing with increasing latitude" (Saar, 1956, p. 58 [see text VI]). For the United States, Merriam (1950) and Halliday (1954) compiled ice cave locations in several different states.

\section{The Early Twenty-First Century}

Today there is greater interest in the geographical distribution of ice caves as shown by Mavlyudov (2008) in the paper "Geography of caves glaciations" and also by "Cave glaciation in the past" (Mavlyudov, 2010), based on historical data. New first descriptions of ice caves are still being published today, often in combination with results from research in the caves as in "First data from a Pyrenean ice cave (A294 cave, Cotiella massif, Spain)" by Ribas and Marcén (2010). The publications of caving organizations in many parts of the world have not been evaluated. These publications probably hold information about ice-cave locations.

\section{General Overview about the History of Ice-Cave Theories}

Since the discovery of ice caves, different theories have been developed, each of which aimed to find a single universal explanation for the origin of subterranean ice. Some of these often contradictory concepts were only discussed for a relatively short period of time, while others are still viable today. Figure 2 shows the chronology of ice cave theories and their development over time based on evaluation of the literature.

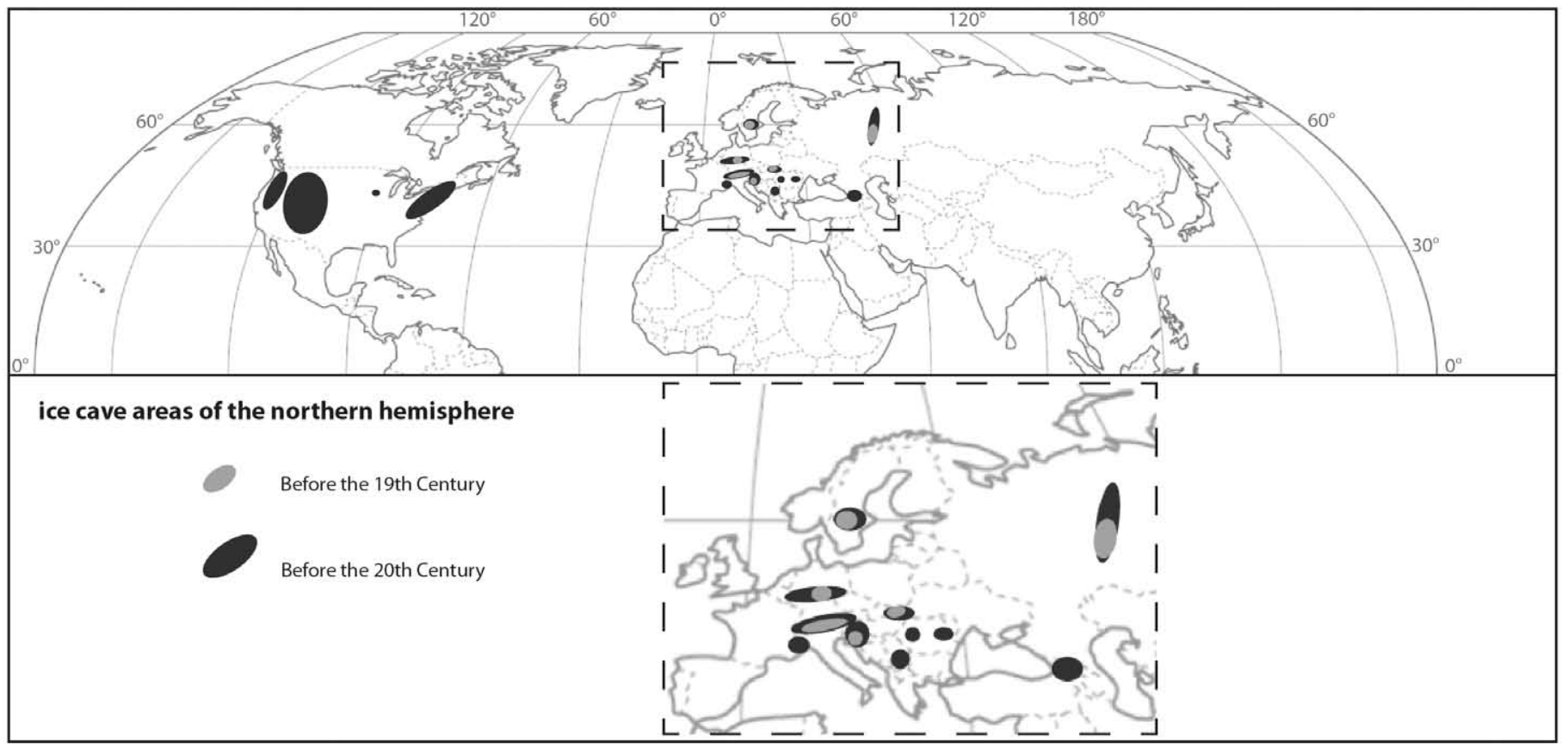

Figure 1. The distributions of known ice cave areas worldwide before the nineteenth and before the twentieth century. 
cave ice as relict of the ice age (1860s)

ice formation due to salt (1712-1816)

ice formation due waves of heat and cold (1840s)

ice formation due to evaporation (1796-1875)

capillary theory (end of 1870s)

summer ice theory (1689-1883)

wintercold theory (1586 till today)

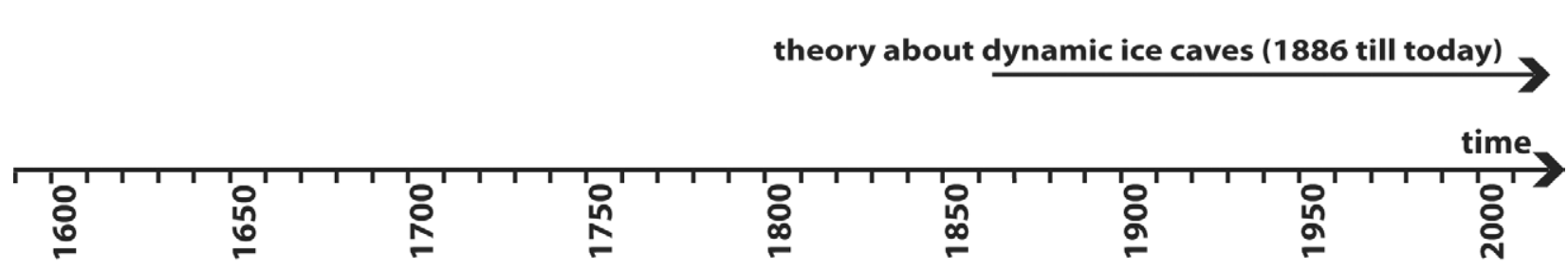

Figure 2. Chronology of ice cave theories over the centuries (Grebe, 2012).

From 1689 to 1883, many authors including Valvasor, Billerez, Behrens, and Scope agreed that ice in caves only formed during the summer months (Fugger 1893). However, they gave different explanations for this phenomenon. The most famous summer ice theory was developed by Pictet in 1822 (reported by Fugger, 1893), who stated that ice only formed due to evaporation driven by air currents, which were stronger in the summer than in the winter. Several measurements and observations, however, disproved the summer ice theory.

Another theory, developed by Billerez and discussed from 1712 to 1816 , held that subterranean ice formed by salt (Fugger 1893). The soil above the cave contained saltpeter and other salts, which dissolved in water and flowed into the cave, where they produced cold through solution. Consequently, the water inside the cave froze. According to Fugger (1893), a chemical analysis by Cossigny in 1743, did not find saltpeter or any other salts needed for such cooling. According to Schwalbe (1886), this theory is only of historic interest, but not scientifically tenable due to the absence of salts in soils.

In 1796, de Saussure published his observations of cold-current caves in the Alps, in which the temperature was reduced by air currents flowing along the wet walls of the cave (cited by Balch 1900). In 1815, Parrot stated that dry and sufficiently deep caves showed steady temperatures of 10 to $12{ }^{\circ} \mathrm{C}$, according to Fugger (1893). Evaporative cooling, however, could lower the temperature until the air was saturated. A steady inflow of warm and dry air led to maximum cooling on hot days. After observations in Saint-Georges and Grand Cave de Matarquis, Thury (1861) disproved the theory that evaporation caused the formation of ice in caves (Balch 1900).

The theory of ice formation through waves of heat and cold was only discussed in the 1840s, when Hope and Herschel explained that ice in caves formed during the summer months when cavern water froze due to the penetration of cold winter waves. In contrast, an advancing warm summer wave led to warmer temperatures, and therefore, melting in winter (Schwalbe 1886). This concept, however, is contradictory to the distribution of soil temperature.

Fugger (1893 and Turri et al. (2009) report that Hitchcock in 1861 and Dawkins in 1876 explained ice in caves as a relic from the Pleistocene. The ice formed during the ice ages and persisted under the surface. According to Schwalbe (1886), the ice age theory has only a minor significance, as most caves have been intermittently ice free and show a steady formation of new ice.

Lowe first formulated the theory that subterranean ice formed by capillary forces. Bubbles of air in water, which flows down through fissures in rocks, are liberated at the bottom of the cave. The air has lost its heat due to its compression, and therefore, absorbs the heat from the air and water in the cave, leading to a decrease in temperature (Balch 1900). However, almost all caves contain dripping water, but not all caves contain ice, which contradicts the theory. In addition, no ice caves are found in hot climates.

Unlike all the theories about the formation of subterranean ice mentioned above, the winter cold theory, as well 
as the theory of the dynamic ice cave, are still viable today. The former was first mentioned by Poissenot (1586), and therefore, is considered the oldest ice cave theory (Fugger 1893). Fugger (1893) cites Prévost as writing in 1789 that caves serve as reservoirs for ice that forms during the winter and does not completely melt during the summer. Also Balch (1900) describes caves as "iceboxes" preserving ice and snow from the winter months, because in the summer warm air cannot enter the cave.

After Thury (1861) made a distinction between static and dynamic ice caves, the latter were not accepted as an independent type until the end of the nineteenth century. Bock (1913) explained the formation of subterranean ice by a temperature decrease resulting from uneven air currents during the summer and winter months. This theory was supported by long-term measurements in ice caves in Austria (Saar 1954).

\section{Summary}

A review of the scientific literature from the twelfth century onward shows that in the beginning only few ice caves, mainly in Europe, were known and described. The knowledge about ice caves was limited, and they were assumed to be a very rare natural phenomenon. In the eighteenth and especially the nineteenth centuries, more and more new and first descriptions as well as review articles were published. By the twentieth century, it had become clear that ice caves are not a rare phenomenon, and the knowledge on ice caves increased. Yet there is more work to do. Today descriptions of new ice caves are often made by caving groups who discover ice caves in remote alpine karst regions. From historic reports, ice cave locations can be reconstructed even if the caves no longer contain ice. All these records can help to understand the geographical distribution of ice caves, as well as the factors determining the formation of ice in caves. The literature described in this paper provides the background for understanding the formation and distribution of ice caves through the world as a basis for the following articles.

\section{References}

Balch, E.S., 1900, Glacières or Freezing Caverns: Philadelphia, Allen, Lane \& Scott, 337 p.

Browne, G.F., 1865, Ice Caves of France and Switzerland: A Narrative of Subterranean Exploration: London, Longmans, Green, and Co., 315 p. Bock H.,1913, Mathematisch-physikalische Untersuchung der Eishöhlen und Windröhren, in Bock, H., Lahner, G., and Gaunersdorfer, G., Die Höhlen im Dachstein: Graz, p. 102-144.

Fugger, E., 1891, Eishöhlen und Windröhren. 1. Teil: Jahresbericht der K. K. Ober-Realschule in Salzburg, Separat-Abdruck 24, Salzburg, Austria.

Fugger, E., 1893, Eishöhlen und Windröhren. Dritter Teil: Jahresbericht der K.K. Ober-Realschule in Salzburg, Separat-Abdruck 26, Salzburg, p. 5-88.

Giradot, A., and Troulliet, L., 1885, La Glacière de Chaux-les-Passavant: Doubs, Sociéte d'Emulation du Doubs, 95 p.

Giradot, A., and Troulliet, L., 1885, La Glacière de Chaux-les-Passavant, in Société d'Emulation du Doubs, ed.: Mémoires de la Société d'Emulation du Doubs. Cinquième série, Volume 9, p. 449-524.

Gollut, L., 1592, Les memoires historiques de la Republique Sequanoise et des Princes de la Franche Comté de Bourgogne: Dôle.

Grebe, Ch., 2012, Eishoelenforschung vom 16. Jahrhundert bis in die Moderne - vom Phaenomen zur aktuellen Forschung [M.S. thesis], Ruhr Universität Bochum.

Halliday, W.R., 1954, Ice Caves of the United States: The American Caver - Bulletin of the National Speleological Society, v. 16, no. 12 , p. 3-28.

Kranjc, A., 2004, Ice and Alpine Caves in Slovenia in older Literature (17th to 19th Century): Acta Carsologica, v. 33, no. 1, p. 61-71.

Mavlyudov, B., 2008, Geography of cave glaciations, in Turri, S., ed., Proceedings of the 3rd International Workshop on Ice Caves, May 12-17, Kungur Ice Cave, Perm, p. 38-44.

Mavlyudov, B., 2010, Cave glaciations in the past, in Proceedings of the 4th International Workshop on Ice Caves, June 5-11th, Obertraun, Austria: Abstract Volume, p. 21.

Merriam, P., 1950, Ice caves: Bulletin of the National Speleological Society, v. 12, p. 32-37.

Poissenot, B., 1586, Nouvelles Histoires Tragiques: Edition établie et annotée par Jean-Claude Arnould et Richard A. Carr: Geneva, Libraire Droz.

Ransanus, P., 1977, Epithoma rerum Hungarorum. Id est Annalium omnium temporum, liber primus et sexagesimus, in Kulcsár, P., ed., Bibliotheca scriptorum medii recentisque aevorum: Akadémiai Kiadó: Budapest, New Series, v. 2.

Ribas, Á.B., and Marcén, C.S., 2010, First data from a Pyrenean ice cave (A294 cave Cotiella massif, Spain), in Spötl, C., Luetscher, M. and Rittig, eds., 4th International Workshop on Ice Caves, June 5-11th, Obertraun, Austria: Abstract Volume, p. 7.

Richter, J.P., 1883, The Literary Works of Leonardo da Vinci: Compiled and Edited from the Original Manuscripts: v. 2: London, Sampson Low, Marston, Searle \& Rivington, $658 \mathrm{p}$.

Saar, R., 1956, Eishöhlen, ein meteorologisch-geophysikalisches Phänomen. Untersuchungen an der Rieseneishöhle (R.E.H.) im Dachstein, Oberösterreich: Geografiska Annaler, v. 38, no. 1, p. 1-63. doi:10.2307/520404.

Schönvinsky, L., 1968, A Kárpát-medence legrégebben ismert jégbarlangja: Karszt és Barlang, [v. 1968], p. 11-16.

Schwalbe, B., 1886, Über Eishöhlen und Eislöcher, nebst einigen Bemerkungen über Ventarolen und niedrige Bodentemperaturen: Berlin, Gaertners Verlagsbuchhandlung $\mathrm{H}$. Heyfelder, $57 \mathrm{p}$.

Schwalbe, B., 1887, Übersichtliche Zusammenstellung literarischer Notizen über Eishöhlen und Eislöcher nebst einigen Zusätzen: Von Prof. Dr. B. Schwalbe (Berlin) Mittheilungen der Section für Höhlenkunde des Österreichischen Touristen-Club, v. 6, no.2-3, p. 13-39.

Silvestru, E., 1999, Perennial ice in caves in temperate climate and its significance: Theoretical and Applied Karstology, vol. 11-12, p. 83-93.

Stein, M.A., 1961, Kalhanaa's Râjataraniginî. A chronicle of the kings of Kashmir, v.1: London, Archibald Constable and Company Ltd., 402 p.

Thury, M., 1861, Etudes sur les glacières naturelles: Archives des Sciences Physiques et Naturelles de Geneve, new series v. 10.

Turri, S., Trofimova, E., Bini, A., and Maggi, W., 2009, Ice caves scientific research history: from XV to XIX centuries: Materialy Glaciologicheskikh Issledovanij, v. 107, p. 156-162. 